\title{
Identification of ancient gilding technology and Late Bronze Age metallurgy by EDXRF, Micro-EDXRF, SEM-EDS and metallographic techniques
}

\author{
Elin Figueiredo • Rui J. C. Silva • M. Fátima Araújo • \\ João C. Senna-Martinez
}

Received: 11 August 2009 / Accepted: 28 December 2009/Published online: 30 January 2010

(C) Springer-Verlag 2010

\begin{abstract}
A combination of analytical techniques capable of elemental and microstructural characterisation was used for the identification of ancient gilding technology and bronze metallurgy. EDXRF, micro-EDXRF, SEM-EDS analysis and metallographic examinations were applied in the study of artefacts dating to the end of the second millennium BC from Crasto de São Romão in Central Portugal. Results report to the finding of an exceptional gilded copper nail among bronze artefacts with 9 wt.\% to15 wt.\% tin and minute other metallic impurities. Additionally, analysis of a crucible fragment points out for bronze production at the archaeological site. EDXRF and micro-EDXRF analysis made on the copper nail
\end{abstract}

Electronic supplementary material The online version of this article (doi:10.1007/s00604-009-0284-6) contains supplementary material, which is available to authorized users.

E. Figueiredo $(\bowtie) \cdot$ M. F. Araújo

Química Analítica e Ambiental, Instituto Tecnológico e Nuclear, Estrada Nacional 10,

2686-953 Sacavém, Portugal

e-mail: elin@itn.pt

E. Figueiredo $\cdot$ R. J. C. Silva

CENIMAT / I3N, Departamento de Ciência dos Materiais,

Faculdade de Ciências e Tecnologia,

Universidade Nova de Lisboa,

2829-516 Caparica, Portugal

\section{E. Figueiredo}

Departamento de Conservação e Restauro,

Faculdade de Ciências e Tecnologia,

Universidade Nova de Lisboa,

2829-516 Caparica, Portugal

J. C. Senna-Martinez

Centro de Arqueologia (Uniarq), Faculdade de Letras,

Universidade de Lisboa,

1600-214 Lisbon, Portugal showed that it was gilded only on the front side of the head, and that the gold layer has been lost in the most exposed areas. SEM-EDS analysis showed that the gold layer has 5-8 $\mu \mathrm{m}$ in thickness and is covered with a thick corrosion layer. The gilding technique is discussed based on the gold layer composition and gold/copper substrate interface. So far, this object seems to be the first diffusion gilded artefact identified in the Portuguese territory dated to Late Bronze Age.

Keywords Archaeometry EDXRF.SEM-EDS · Gold . Copper $\cdot$ Bronze

\section{Introduction}

The first use of metals and the early development of metallurgy was an essential stage that gave human kind a strong technological background, crucial to the present developments. The use of metal during the pre-historical times is such important evidence that chronological periods in the Old World have been named after the type of metal that was being worked: "Copper Age", "Bronze Age" and "Iron Age".

Multidisciplinary studies covering the field of cultural heritage are becoming more and more common improving our knowledge of the history of technology. Recently, the development of new methods and an easier access to sophisticated equipments has allowed new and original multi-analytical approaches adapted to the nature of each single cultural object [1,2].

Amongst the wide variety of modern analytical techniques that are employed in the study of metals (some examples in [3-7]), energy dispersive X-ray fluorescence (EDXRF) and scanning electron microscopy with energy 
dispersive analysis (SEM-EDS) for elemental analyses and electronic and optical microscopy (OM) for microstructural studies are well established techniques (some examples in [8-14]). EDXRF, either in its conventional form or as micro-XRF, and SEM-EDS can be described as nondestructive (i.e. respecting the physical integrity of the material/object) or micro-invasive (i.e. in the sense that sampling or cleaning of a small surface is frequently required), multielemental, relatively fast and versatile, allowing average compositional information but also local information of small areas [15]. The electronic and optical microscopies are able to provide a wide range of information on metallurgical features and conservation state of the objects, and the metallographic approach can be considered easy to apply, not expensive, a flexible and adaptable research tool [16].

In the present work a number of objects that are part of a larger set of metallic artefacts and metallurgical debris found in Cabeço do Castro de São Romão (CSR), located near Seia, Portugal, are being studied. The site has been excavated during the 80 's of the preceding century and the artefacts were found in a layer that has been radiocarbon dated to a period ranging from 1270 to $1060 \mathrm{cal} \mathrm{BC}(2 \sigma$ probability), and thus perfectly incorporated in the Late Bronze Age (LBA) period of the region [17]. The entire set of metallic artefacts has been analysed by EDXRF in the late 80 's, in a preliminary study by Gil et al [18]. Analytical results made over the artefacts patinated surface (often enriched in Sn [19]) showed that all artefacts were made of bronze with varying vestiges of $\mathrm{As}, \mathrm{Ag}, \mathrm{Sb}$ and $\mathrm{Pb}$ except for a decorative nail, which was made of copper. Besides the different bulk composition, the decorative nail also presented unusual vestiges of Au.

Very recently a reappraisal and more comprehensive study of the LBA metallurgy in the Portuguese territory is being done by an interdisciplinary team, from which the present authors take part. New EDXRF analyses, here presented and discussed, made on different areas of the nail revealed that Au was only present in the front side of the nail's head. This exceptional feature demanded detailed investigations and a multi-analytical approach was adopted.

As a consequence, the copper nail, some bronze artefacts and a crucible fragment were selected for analyses. The aim was to investigate the manufacturing techniques used during LBA, such as gilding and bronze artefact production. This study required analytical techniques adequate for chemical characterisation of the surfaces and interfaces as well as microstructural examination. Due to the uniqueness of the copper nail, complex structures and altered state of most cultural heritage objects including these, the selection of analytical techniques and experimental procedures was done cautiously, balancing the type of information provided and the minimum physical and chemical intervention on the objects. Therefore conventional EDXRF and microEDXRF elemental analysis were selected due to their nondestructive, relatively fast and complementary character and SEM-EDS was selected to the detailed study of the gilding technique. Metallographic preparations on the bronze artefacts were performed using different procedures, accordingly to the characteristics of each object.

\section{Background on bronze, composite artefacts and gilding techniques}

Bronze $(\mathrm{Cu}-\mathrm{Sn}$ alloy) began to be used as early as the end of the 3rd millennium BC in some Western European areas such as Great Britain, but it was only by the end of the 2nd millennium $\mathrm{BC}$ (at the start of LBA) that it became the main metal used [20]. In the Iberian Peninsula, the use of bronze had generically a late start, but by LBA bronze had practically substituted copper in the production of the various types of artefacts. In the Iberian Peninsula the alloy had frequently $\sim 9-14$ wt.\% $\mathrm{Sn}$ and presented $\mathrm{Pb}$ and $\mathrm{As}$ as impurities [21-23]. This composition distinguishes the Iberian bronze - binary bronze - from most bronze that was circulating in other Atlantic areas, where $\mathrm{Pb}$ contents were frequently in the order of several percent- ternary bronze [23].

Composite objects made by joining different metals and dated to Bronze Age are known, however they are not very usual. Bronze artefacts with copper rivets are one of the most common examples [24]. A LBA blade made of iron with a handle made of bronze is another example, this one from Castro de Baiões (Portugal), involving one of the first Iberian iron objects [17] — probably a reflection of contacts with Eastern Mediterranean territories where iron was already at use. Gold attached to other metals is particularly rare in European areas and from the Iberian Peninsula one can report the hilt of the Middle Bronze Age sword from Guadalajara (Spain) which is covered with embossed gold sheet [25].

The application of a gold layer to the surface of a less noble metal, a process known as gilding, came into favour from about the 3rd millennium BC in the Middle East [26, 27]. It gave the appearance of solid gold [28] allowing a greater use of the limited gold available. The first techniques involved mechanical attachment of relatively thick sheets of gold foil into a metallic surface by riveting or by cutting grooves into the surface of the base metal. Other procedures emerged as gold refining techniques developed, probably early in the 2nd millennium BC [26]. The use of very pure gold allowed a significant reduction in the gold sheet thickness by hammering [26, 29] resulting in savings in the amount of gold required. In fact, in Egypt the beating of gold was depicted on tomb paintings and was 
mentioned in a funerary papyrus from the fourteenth century $\mathrm{BC}$ decorated with thin gold leaf pointing out to a specialised craft [26]. One of the emerging techniques was the attachment of a thin sheet of gold to the substrate, that could be metal or some intermediate ground layer such as calcite or gypsum, using an organic adhesive [27]. Another technique was diffusion bonding. This seems to have been the most common gilding technique for metallic objects in the Eastern Ancient World before the invention of mercury amalgam gilding around the second century BC [28].

Diffusion bonding was employed from at least as early as c.1200 BC [26] and involved burnishing the gold directly to a scrupulously cleaned metal base and then heating it gently to cause interdiffusion among the two metals [27]. Unlike a mechanically gilded metal surface, a diffusion-gilded surface could be further worked and shaped with less risk of detachment of the coating [28]. Additionally, the very strong bonding among the two metals made it more resistant to wear and tear [26]. This technique revealed good results on a silver or pure copper substrate but not on a bronze alloy when the use of a burnishing tool was necessary [30].

\section{Experimental}

Materials and methods

Five artefacts were selected for analyses (Fig. 1):

- a decorative copper nail (CSR-3000) exhibiting a dark blackish and reddish patina all over the surface, weighting $5.08 \mathrm{~g}$;

- a bronze spearhead fragment (CSR-7003) exhibiting a greenish patina, weighting $6.20 \mathrm{~g}$;

- a bronze awl fragment (CSR-3169) which has an irregular rectangular cross-section of $\sim 2 \times 3 \mathrm{~mm}$, weighting $1.09 \mathrm{~g}$;

- a bronze bar fragment (CSR-4660) which has an irregular quadrangular cross-section of $\sim 4 \times 4 \mathrm{~mm}$, weighting $1.69 \mathrm{~g}$;

- a small top border fragment of a crucible (CSR-7006) weighting $4.11 \mathrm{~g}$.

Conventional EDXRF analyses were performed, at a first stage, on all the items over different areas. The analyses were conducted in a Kevex 771 spectrometer ([31] and Electronic Supplementary Material), with no surface preparation. Regarding the metallic items it allowed the evaluation of any special features such as the presence of composite objects. In the case of the crucible fragment, it allowed an evaluation of its use in ancient metallurgical operations.

Small samples, but representative of the cross-section, were taken from the awl and bar fragments for metallographic preparation. On the spearhead fragment no sample was taken due to its stronger aesthetical feature, but a small area at a border was prepared for metallographic observation. All the prepared surfaces were examined in an Optical Microscope Leica DMI5000M (http://www.leica-microsystems.com/). Etching was made using an aqueous ferric chloride solution.

Elemental composition was obtained through microEDXRF analyses over the previous prepared areas before etching. These were performed in an ArtTAX Pro spectrometer (http://www.bruker-axs.de/artax.html and Electronic Supplementary Material) and quantitative analysis was made through WinAxil software (http://www.canberra.com/ products/438012.asp) using the fundamental parameter method and experimental calibration factors that were calculated with the reference material Bronze 551 from British Chemical Standards (http://www.basrid.co.uk/bas.htm).

Various micro-EDXRF analyses were also performed on the decorative nail without surface preparation. Additionally, a small area (at an edge) was cleaned form the most superficial corrosion and was grinded (manually, using no water) for examination under a SEM-EDS without a conductive coating (see Electronic Supplementary Material). The SEM examinations were performed in a Zeiss DSM 962 equipment (http://www.zeiss.com) with an energy dispersive spectrometer (EDS) from Oxford Instruments INCAx-sight (www.oxford-instruments.com) with an ultra thin window that enables the detection of low atomic number elements, such as carbon and oxygen. Semiquantifications were made using ZAF correction procedure.

\section{Results and discussion}

Results are presented in the following sections accordingly to the nature of the objects and analytical techniques employed.

EDXRF, micro-EDXRF and SEM-EDS study of the gilded copper nail

Results of the EDXRF analyses made on both sides of the decorative nail, the front and reverse surfaces, show the presence of $\mathrm{Cu}$ as major element, vestiges of $\mathrm{Pb}, \mathrm{Sn}, \mathrm{Ag}$ in both sides, and the presence of $\mathrm{Au}$ just on the front side (Fig. 2). Other elements were detected, such as $\mathrm{Fe}$ and $\mathrm{Ca}$, and their presence is probably due to the incorporation of soil particles in corrosion during burial.

Since Au was only detected in the front side, the analyses suggest that the nail is made of copper (with $\mathrm{Pb}$, $\mathrm{Ag}, \mathrm{Sn}$ and $\mathrm{Sb}$ impurities) with a deliberate gilded surface only on the visible side.

The use of a copper substrate on the decorative nail instead of a bronze one suggests that it was either an 


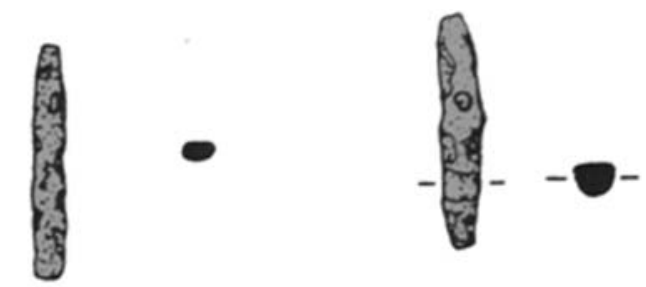

\section{CSR-3169 CSR-4660}

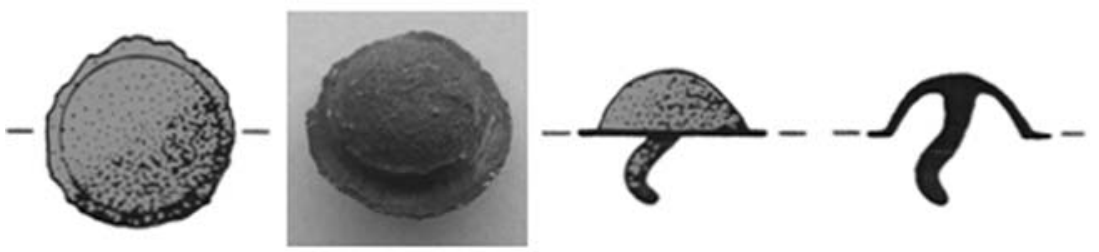

\section{CSR-3000}
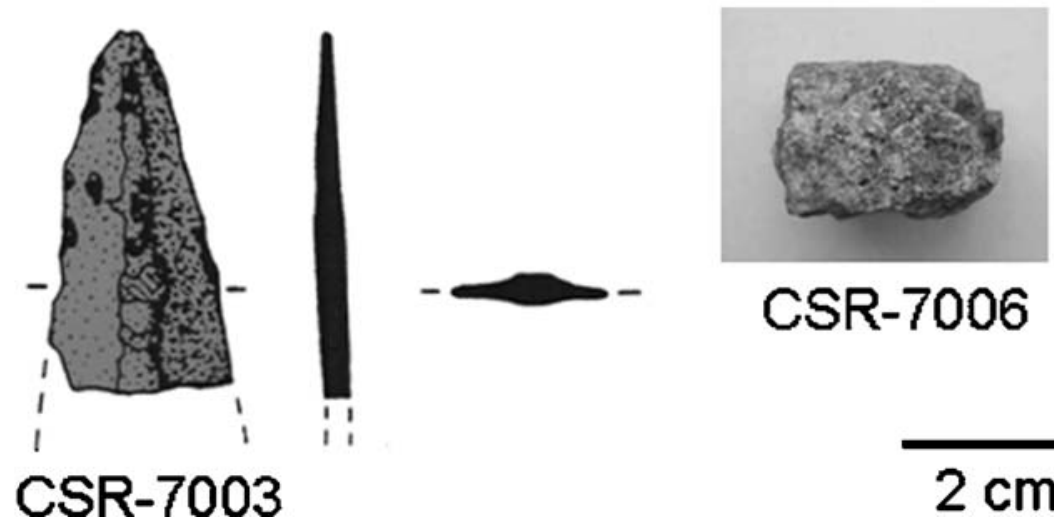

CSR-7006

Fig. 1 Drawings of the four metallic objects selected for the study after Gil et al [18] and photographs of the front side of the nail (CSR-3000) and the crucible fragment (CSR-7006)

economic choice-copper could be less valuable than bronze - or an intentional technological decision.

The front surface of the nail is covered with a dark corrosion that exhibits a few particular small areas with a gold shine. In the most exposed regions this dark corrosion has been lost revealing a red-brownish colour. Presuming that an Au gold layer was still preserved in some areas of the front surface, micro-EDXRF analyses were conducted

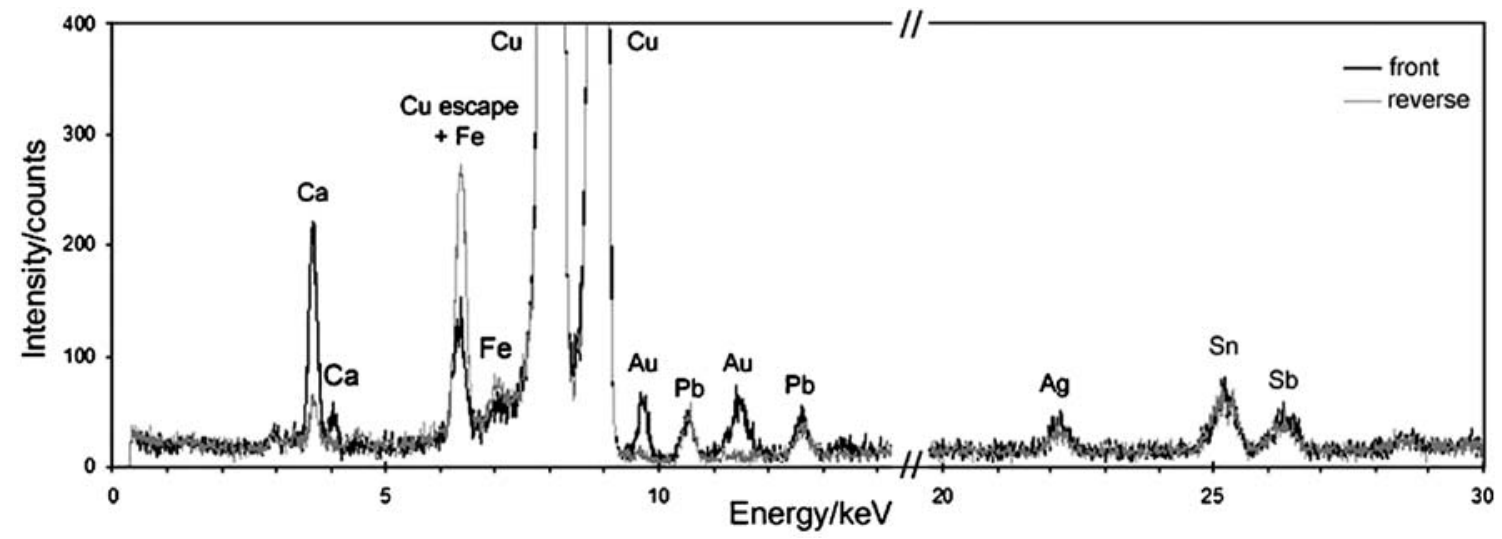

Fig. 2 EDXRF spectra of the front and the reverse sides of the decorative copper nail (CSR-3000) 
on various spots in order to evaluate the extension of the gold layer. Au was detected in the analyses performed over the dark corrosion and over the metallic shine areas, not in the red-brownish regions (see Electronic Supplementary Material). This suggests that the gold layer has been lost in most exposed areas, probably due to a deep corrosion development and its detachment.

The SEM examination was conducted in the next stage at an edge of the head of the nail-representative of a crosssection-where the dark corrosion layer was still preserved.

Low BSE magnification observations and EDS analyses showed a distinct layer of gold between the copper base metal that was partially oxidized and the corrosion layer that reached frequently $>200 \mu \mathrm{m}$ in thickness and was composed by $\mathrm{C}, \mathrm{O}, \mathrm{Al}, \mathrm{Si}, \mathrm{P}, \mathrm{K}$ and Fe, besides $\mathrm{Cu}$. This corrosion layer, which represents the dark areas observed on the front surface of the head of the nail, can be interpreted as a mixture of soil particles and copper salts that were leached out from the nail body during corrosion processes. Generally, the cohesion between the gilding and the copper base is very good (only few regions have the $\mathrm{Au}$ layer damaged) (Fig. 3), suggesting either the use of a quite durable adhesive or that some diffusion among the metals has taken place. Any mechanical attachment would most likely lead to the formation of a strong corrosion among the two metals, in the same way as the use of a less durable organic adhesive that would easily decay under burial [32, 33].

Detailed examination of the gold layer showed that it was quite thin, ranging 5-8 $\mu \mathrm{m}$ in thickness-Fig. 4 reports to the main results of the gold layer features. In some particular areas more than one layer was visible suggesting folding of individual sheets or detachment of top regions of the gold rich layer, like "flaking", probably as a result of damage provoked by corrosion (some "flaking" is also observed in Fig. 3, at the right). The EDS analyses made on various spots of the gold layer only detected the presence of $\mathrm{Au}$ and $\mathrm{Cu}$ metallic elements (Fig. $4 \mathrm{a}$ ) with $\mathrm{Cu}$ regularly in contents $>50$ wt. $\%$. The absence of Ag suggests the use of refined gold since this element is commonly present in native gold; native gold may attain silver concentrations up to $40 \%$, copper up to $1 \%$ and iron up to $5 \%$ [34]. The high amount of copper present in the gold layer suggests that it is not likely to be original or deliberately added to the gold since it would not facilitate the hammering of the gold sheet. Its presence suggests in-situ incorporation, either due to: corrosion of the base copper (i.e. migration of copper species); technological features (e.g. diffusion bonding); or a combination of both.

When a durable adhesive has been used it has occasionally been detected in SEM-EDS analyses [35]. In the present case no area below the gold layer has particular features detected by EDS, such as extremely carbon-rich. Instead, the gold/copper interface is regularly characterized by the presence of more or less pronounced gold rich extensions penetrating into the copper metal, visible in BSE images (Fig. 4). This feature, commonly called "fingers" in literature, has been reported as typical in objects gilded by diffusion bonding $[28,35]$. It has been explained as a result of preferential diffusion of gold along grain boundaries of the substrate metal, enhanced in BSE image contrast due to the oxidation of the substrate [28].

Another feature occasionally reported as a criterion for identifying a diffusion bonding technique is a compositional gradient across the gilding layer in a cross-section [28]. Diffusion is temperature (and time) dependent and processed in two-way. In the case of gold and copper, the rates of diffusion are unequal since copper migrates more rapidly into gold than vice versa [36]. The higher the temperature and the time involved, larger is the diffusion zone. In ancient objects, these have been reported to range from only a few micrometers to more than fifty micrometers [28]. In the present case, since the EDS spatial resolution (1-2 $\mu \mathrm{m})$ is close to the thickness of the gold rich layer, a compositional gradient through an EDS line-scan is not conclusive (Fig. 4b).

Detailed observations of the copper body showed some dispersed inclusions. Spot EDS analyses made on some of them identified various associations of the $\mathrm{Sb}, \mathrm{As}, \mathrm{Pb}$ and Ag elements (see Electronic Supplementary Material). Most

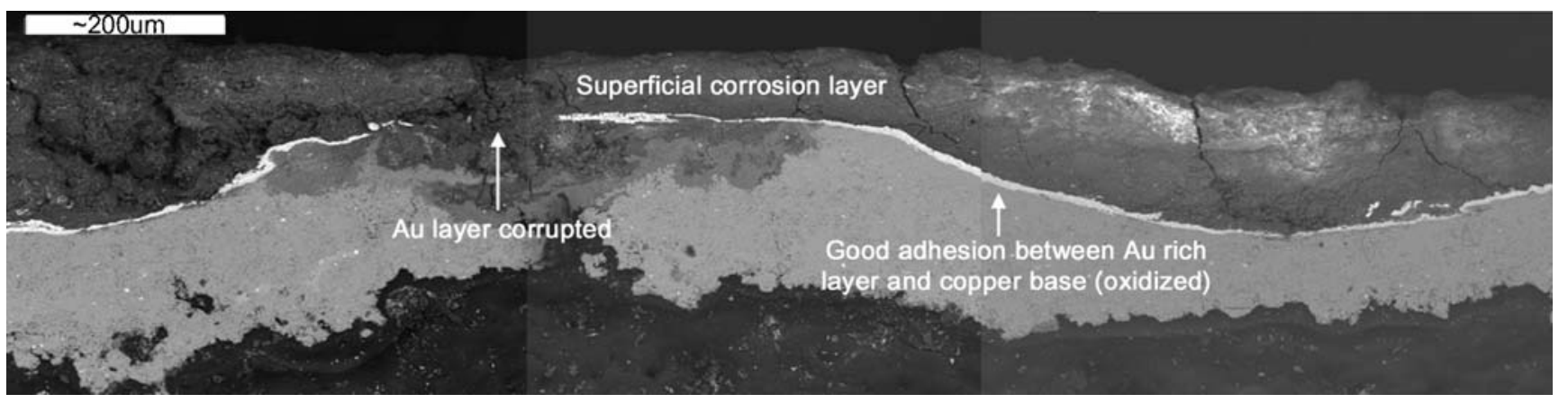

Fig. 3 SEM (BSE) image of a general view of a region of the prepared area in the nail (CSR-3000) 
(a)
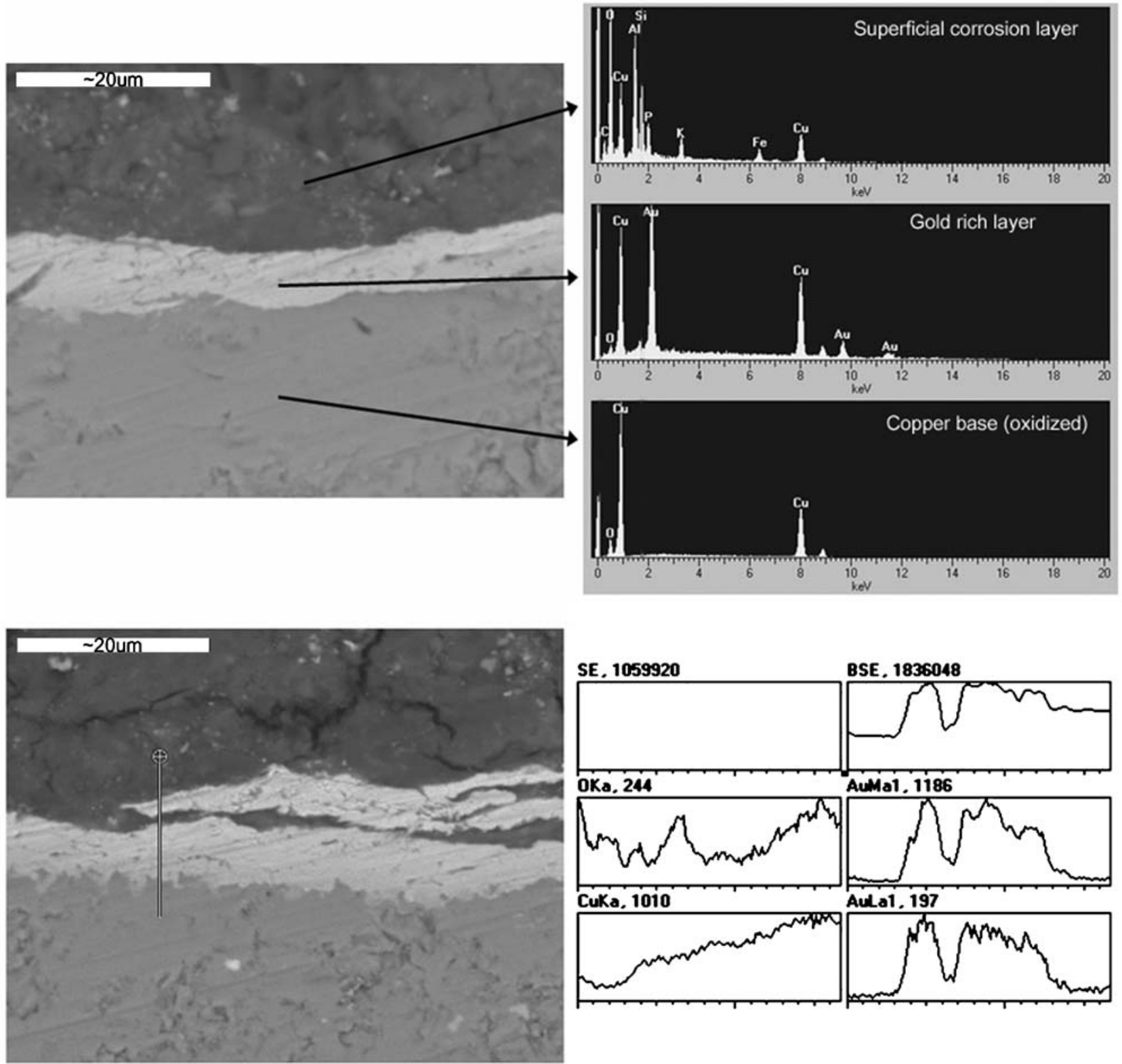

(b)

Fig. 4 a SEM (BSE) image of the gold rich layer in the nail (CSR3000) and EDS spectra of corrosion layer, gold rich layer and copper substrate. b SEM (BSE) image on another area of $t$ the gold rich layer

of these elements had previously been detected in the EDXRF analyses. Such elements have also been detected in copper artefacts from other Bronze Age Portuguese sites such as a bar fragment from Castro de Baiões (unpublished work) and two artefacts from Fraga dos Corvos site in Northern Portugal [37].

Taking into consideration all the experimental results, a bonding through diffusion seems to be the most probable technique used. It would explain (1) the use of copper to produce the base metal in a period and region where nearly all the artefacts were produced in bronze (see also next sections), (2) the good cohesion between the gold and and EDS line scan with oxygen $(\mathrm{O} \mathrm{Ka})$, copper $(\mathrm{Cu} \mathrm{Ka})$ and gold $(\mathrm{Au}$ $\mathrm{Ma}$ and $\mathrm{Au} \mathrm{La)} \mathrm{distribution}$

copper substrate in most areas, (3) the morphology of gold/ copper interface in these areas and (4) the high amount of copper in the gold layer.

EDXRF, Micro-EDXRF and metallographic study of the bronze artefacts

The EDXRF analyses showed, as the previous ones performed by Gil et al. [18], that the three artefacts are made of binary bronze with minor impurities. The microEDXRF analyses made on the prepared areas showed that the bronze alloy has $9 \mathrm{wt} . \%$ and $15 \mathrm{wt} . \% \mathrm{Sn}$, being the bar 

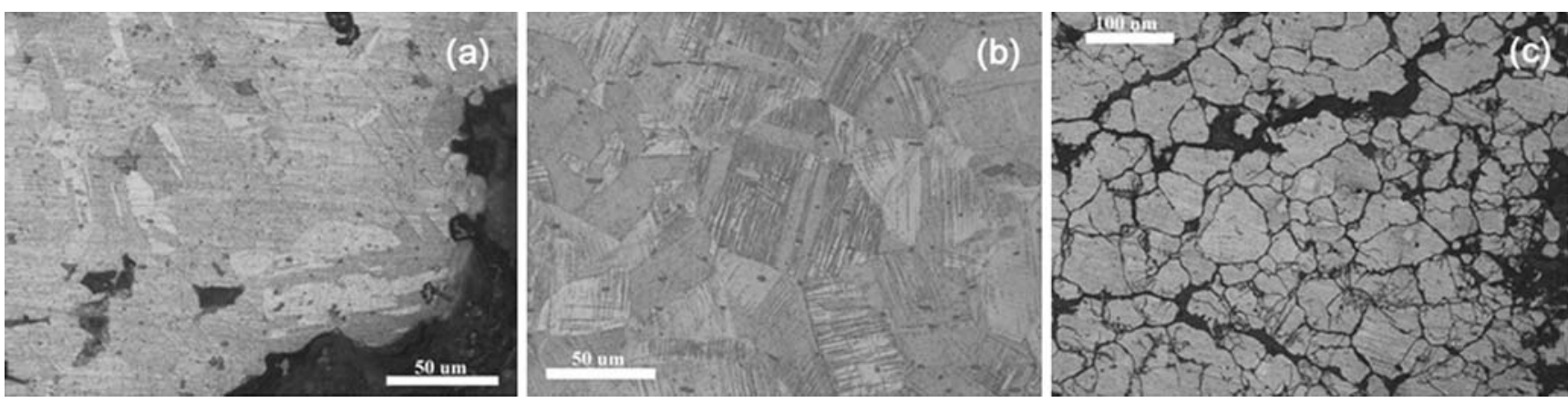

Fig. 5 Detail of the microstructure of the (a) spear head fragment (CSR-7003), (b) awl fragment (CSR-3169) and (c) bar fragment (CSR-4660) (OM, Bright Field, etched)

fragment CSG-4660 the one with the highest content (see Electronic Supplementary Material).

In Fig. 5 some images related to the metallographic observations made under the OM are shown. The spearhead has a recrystallized grain structure composed by single $\alpha$ phase twinned grains (Fig. 5a). This indicates that after casting (moulds for casting spearheads are known in the region and a fragment was found at CSR) the item was subjected to some cycles of hammering and annealing. Still, no major change in shape has occurred since the numerous blue-grey $\mathrm{Cu}-\mathrm{S}$ inclusions still detain the irregular shapes they obtained in the interstitial interdendritic regions during solidification. Furthermore, many of the twin lines are bent indicating that a post-annealing deformation has occurred. This deformation may be a result of the last stage in the manufacturing process (as hammering) or other posterior actions, as those involving its use.

The CSR-3169 awl fragment has been extensively worked to shape and has a completely recrystallized twinned grain structure. Most of the twinned crystals exhibit a high concentration of slip bands (Fig. 5b). These are probably a result from a severe final cold work of the item. Furthermore, there are many $\mathrm{Cu}-\mathrm{S}$ inclusions which are flattened and elongated, corroborating the extensive work done during the item manufacture. The manufacture of the awl was probably done through the shaping of a cast bar since moulds for bar production have been found in CSR site as well as in other LBA Baiões/Santa Luzia habitat sites [17].

The bar fragment CRS-4660 is composed of primary $\alpha$ grains and a few $\alpha+\delta$ eutectoid structures. Some inclusions of $\mathrm{Cu}-\mathrm{S}$ are also visible in intergranular regions. Extensive intergranular corrosion has occurred outlining most of the grain boundaries. Some intragranular corrosion is also observed, that in some areas follow crystallographic planes suggesting that the bronze must have suffered some plastic deformation during manufacturing or use (Fig. 5c).

Likely, the awl and bar fragment have been shaped from similar cast bars, since the awl is the one with the smallest cross-section and also the one with the most worked microstructure. The deeper intergranular corrosion on the bar fragment comparatively with the awl is probably due to a less homogenized structure, as a result of a smaller amount of thermomechanical actions. Furthermore, the extensive corrosion can be an explanation to the higher Sn content measured in this artefact.

\section{EDXRF study of the crucible fragment}

Non-invasive EDXRF analyses were performed on five areas of the crucible fragment. All of them showed the present of two elements related with ancient metallurgy: $\mathrm{Cu}$ and $\mathrm{Sn}$. Other elements such as $\mathrm{Fe}, \mathrm{Sr}, \mathrm{Rb}, \mathrm{Y}$ and $\mathrm{Zr}$ were also detected and are a result from the crucible raw material. In Fig. 6 one of the EDXRF spectra is represented. This analysis demonstrates that the crucible has been used in bronze metallurgy, most likely has contained binary bronze. This makes probable the existence in CSR of a local metallurgical production of artefacts such as those analysed in this work.

Furthermore, the practice of binary bronze metallurgy at the site is in agreement with the metallurgical tradition of the region and with most bronze that was in circulation in the central Portuguese area and other Iberian areas during this period [21-23].

\section{Conclusions}

The present study highlights the importance of the use of multi-analytical approaches in the cultural heritage field, in

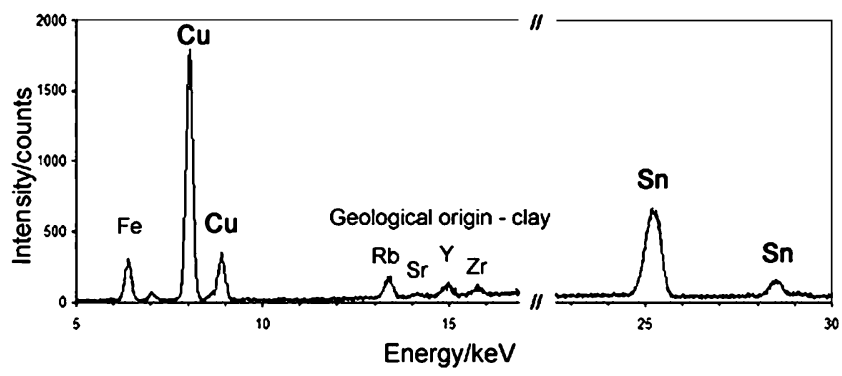

Fig. 6 EDXRF spectrum of the crucible fragment (CSR-7006) 
particular for the identification of an ancient gilding technology and bronze metallurgy. The conventional EDXRF analyses showed to be an excellent primary tool, allowing investigations in large areas without surface preparation. This technique revealed that the copper nail had the front surface gilded, even if no gold layer was visible due to a thick external corrosion layer. It also demonstrated to be especially useful in the evaluation of the use of the crucible fragment, even if no metallic relics were visible. In the archaeometric field it certainly also has good potential in the evaluation of the use of clay and stone moulds. Micro-EDXRF was successfully used in the analyses of small particular and prepared areas, allowing the study of metal composition with minimum damage to the objects. It was also important in the evaluation of the state of conservation of the gold layer in the nail, showing that gold layer was absent in the most exposed areas. SEMEDS was performed in a small prepared area of the nail without a conductive coating, avoiding the introduction of external elements in the analysed surface. This was significant since the two elements usually used in the sputtering of the surface, $\mathrm{Au}$ or $\mathrm{C}$, were important elements in the investigation of the gilding technology. The metallographic investigations showed that various thermomechanical sequences have been performed on the bronze artefacts after casting and suggest that the resulting microstructures have influence in the corrosion deepness.

Evidences of diffusion gilded artefacts are lacking in Western European LBA contexts, in contrast to the more Eastern Mediterranean Ancient World. This suggests that beside the practice of a very specific, traditional, bronze metallurgy in CSR, new technological innovations were adopted, as the diffusion gilding, probably a result of fardistance contacts, as with Eastern Mediterranean societies. This point out to the importance that Iberian Peninsula must have had during Late Bronze Age as a meeting point between Atlantic and Mediterranean traditions.

Acknowledgments This work has been carried out in the framework of the project METABRONZE (Metallurgy and Society in Central Portugal Late Bronze Age, POCTI/HAR/58678/2004) financed by the Portuguese Science Foundation (FCT). E.F. acknowledges the FCT for the SFRH/BD/ 27358/2006 grant and is thankful to Cristiana Nunes for her valuable comments and suggestions to an early version of the manuscript.

\section{References}

1. Adams F, Adriaens A, Aerts A, De Raedt I, Janssens K, Schalm O (1997) Micro and surface analysis in art and archaeology. J Anal Atom Spectrom 12:257-265

2. Reiche I, Chalmin E (2008) Synchrotron radiation and cultural heritage: combined XANES/XRF study at Mn K-edge of blue, grey or black coloured palaeontological and archaeological bone material. J Anal Atom Spectrom 23:799-806
3. Artoli G (2007) Crystallographic texture analysis of archaeological metals: interpretation of manufacturing techniques. Appl Phys A 89:899-908

4. De Ryck I, Adriaens A, Pantos E, Adams F (2003) A comparision of microbeam techniques for the analysis of corroded ancient bronze objects. Analyst 128:1104-1109

5. Doménech-Carbó A, Doménech-Carbó MT, Martínez-Lázaro I (2008) Electrochemical identification of bronze corrosion products in archaeological artefacts. A case study. Microchim Acta 162:351-359

6. Grolimund D, Senn M, Trottmann M, Janousch M, Bonhoure I, Scheidegger AM, Marcus M (2004) Shedding new light on historical metal samples using micro-focused synchrotron X-ray fluorescence and spectroscopy. Spectrochim Acta B 59:16271635

7. Thornton C, Lamberg-Karlovsky CC, Liezers M, Young SMM (2002) On pins and needles: tracing the evolution of copper-base alloying at Tepe Yahya, Iran, via ICP-MS analysis of commonplace items. J Archaeol Sci 29:1451-1460

8. Ferrer Eres MA, Valle-Algarra M, Gimeno Adelantado JV, PerisPricente J, Soriano Piñol MD, Mateo-Castro R (2008) Archaeometric study on polymetallic remains from the archeological dig in Lixus (Larache, Morocco) by scanning electron microscopy and metallographic techniques. Microchim Acta 162:341-349

9. Figueiredo E, Araújo MF, Silva R, Braz Fernandes FM, SennaMartinez JC, Inês Vaz JL (2006) Metallographic studies of copper based scraps from the Late Bronze Age Santa Luzia archaeological site (Viseu, Portugal). In: Fort R, Alvarez de Buergo M, Gomez-Heras M, Vazquez-Calvo C (eds) Heritage, weathering and conservation, vol.I. Taylor and Francis, London, pp 143-149

10. Gimeno Adelantado JV, Ferrer Eres MA, Valle Algarra FM, Peris Vicente J, Bosch Reig F (2003) Application of SEM/EDX and metallographic techniques to the diachronic study (6th-18th century) of metallurgical materials found in archaeological excavations on the island of Ibiza (Spain). Anal Bioanal Chem 375:1161-1168

11. Giumlia-Mair A (2005) On surface analysis and archaeometallurgy. Nucl Instrum Meth B 239:35-43

12. Ingo GM, De Caro T, Riccucci C (2006) Large scale investigation of chemical composition, structure and corrosion mechanism of bronze archaeological artefacts from Mediterranean basin. Appl Phys A 83:513-520

13. Kienlin TL, Bischoff E, Opielka H (2006) Copper and bronze during the eneolithic and early bronze age: a metallographic examination of axes from the northalpine region. Archaeometry 48:453-468

14. Silva RJC, Figueiredo E, Araújo MF, Pereira F, Braz Fernandes FM (2008) Microstructure interpretation of copper and bronze archaeological artefacts from Portugal. Mater Sci Forum 587588:365-369

15. Janssens K, Vittiglio G, Deraedt I et al (2000) Use of microscopic XRF for non-destructive analyses in art and archaeometry. X-Ray Spectrom 29:73-91

16. Pinasco MR, Ienco MG, Piccardo P, Pellati G, Stagno E (2007) Metallographic approach to the investigation of metallic archaeological objects. Ann Chim-Rome 97:553-574

17. Senna-Martinez JC (2000) O “Grupo Baiões/Santa Luzia” no Quadro do Bronze Final de Centro de Portugal. In: Senna-Martinez JC, Pedro I (eds) Por Terras de Viriato. Governo Civil do Distrito de Viseu and Museu Nacional de Arqueologia, Viseu, pp 117-146

18. Gil FB, Senna-Martinez JC, Guerra MF, Seruya AI, Fabião C (1989) Produções metalúrgicas do Bronze Final do Cabeço do Crasto de São Romão, Seia: uma primeira análise. In: Actas do I Colóquio Arqueológico de Viseu, Colecção Ser e Estar 2, pp 235 248

19. Figueiredo E, Valério P, Araújo MF, Senna-Martinez JC (2007) Micro-EDXRF surface analyses of a bronze spear head: lead 
content in metal and corrosion layers. Nucl Instrum Meth B 580:725-727

20. Pare C (2000) Bronze and the Bronze Age. In: Pare CFE (ed) Metals make the World go Round. Oxbow, Oxford, pp 1-38

21. Vilaça R (1997) Metalurgia do Bronze Final da Beira Interior: revisão dos dados à luz de novos resultados. Estudos PréHistóricos V:123-154

22. Valério P, Araújo MF, Canha A (2007) EDXRF and microEDXRF studies of Late Bronze Age metallurgical productions from Canedotes (Portugal). Nucl Instrum Meth B 263:477482

23. Rovira S, Gómez P (1998) The Ria de Huelva hoard and the Late Bronze Age metalwork: a statistical approach. In: Mordant C, Pernot M, Rychner V (eds) L'Atelier du Bronzier en Europe du XXe au VIIIe Siècle avant notre Ère. CTHS, Paris, pp 81-90

24. Northover P, Anheuser K (2000) Gilding in Britain: Celtic, Roman and Saxon. In: Drayman-Weisser T (ed) Gilded MetalHistory, Technology and Conservation. Archtype and The American Institute for Conservation of Historic and Artistic Works, London, pp 109-121

25. Rovira S (2002) Metallurgy and Society in Prehistoric Spain. In: Ottaway BS, Wagner EC (ed). Metals and Society, BAR IS1061, Oxford, pp 5-20

26. Oddy A (2000) A History of Gilding with particular reference to statuary. In: Drayman-Weisser T (ed) Gilded Metal-History, Technology and Conservation. Archtype and The American Institute for Conservation of Historic and Artistic Works, London, pp 1-19

27. Oddy A (1981) Gilding through the Ages. Gold Bull 14:75-79

28. Gänsicke S, Newman R (2000) Gilded silver from Ancient Nubia. In: Drayman-Weisser T (ed) Gilded Metal-History, Technology and Conservation. Archtype and The American Institute for Conservation of Historic and Artistic Works, London, pp 73-96

29. Nicholson ED (1979) The ancient craft of gold beating. Gold Bull 12:161-166

30. Healy JF (1999) Pliny the Elder on science and technology. Oxford University Press, New York

31. Araújo MF, Alves LC, Cabral JMP (1993) Comparison of EDXRF and PIXE in the analysis of ancient gold coins. Nucl Instrum Meth B 75:450-453

32. Selwyn L (2000) Corrosion chemistry of gilded silver and copper. In: Drayman-Weisser T (ed) Gilded Metal-History, Technology and Conservation. Archtype and The American Institute for Conservation of Historic and Artistic Works, London, pp 21-47

33. Strahan DK, Maines CA (2000) Lacquer as an adhesive for gilding on copper alloy sculpture in southeast Asia. In: DraymanWeisser T (ed) Gilded Metal-History, Technology and Conservation. Archtype and The American Institute for Conservation of Historic and Artistic Works, London, pp 185-201

34. Guerra MF, Calligaro T (2003) Gold cultural heritage objects: a review of studies of provenance and manufacturing technologies. Meas Sci Technol 14:1527-1537

35. Griffin PS (2000) The selective use of gilding on Egyptian Polychromed Bronzes. In: Drayman-Weisser T (ed) Gilded MetalHistory, Technology and Conservation. Archtype and The American Institute for Conservation of Historic and Artistic Works, London, pp 49-72

36. Pinnel MR (1979) Diffusion-related behaviour of gold in thin film systems. Gold Bull 12:62-71

37. Figueiredo E, Senna-Martinez JC, Silva RJC, Araújo MF (2009) Orientalizing Artifacts from Fraga dos Corvos Rock Shelter in North Portugal. Mater Manuf Process 24:949-954 